\title{
A Course Exploration: Guiding Instruction to Prepare Students as Change Agents in Educational Reform
}

\author{
Kathy L. Church, EdD \\ Associate Professor, Graduate School of Education and Psychology \\ Pepperdine University
}

\begin{abstract}
This article explores the premise of teacher identity development through course experiences directed at inquiry and social awareness. The course exploration examines the use of various strategies used to help promote educators as change agents. Pre-service students enrolled in a one-year master's program with teaching credential participated in a yearlong course designed to engage them in guided inquiry while making connections between theory and practice. Evaluation of the projects and student perceptions of their work suggest that guided inquiry into educational issues builds critical thinking skills and a sense of purpose, leadership, and service through shaping teacher identity.
\end{abstract}

With the realities of today's criticisms of teacher education and the established need for high quality teachers, teacher education programs must be exemplary in creating effective educational paths for tomorrow's educators. Doubtful attitudes toward teacher education programs are quick to point out 'real' learning can only take place in the classroom (Britzman, 2003). Yet, it is well established that it is the responsibility of teacher education programs to prepare quality teachers (DarlingHammond \& Bransford, 2005).

Preparing quality teachers to serve diverse populations within an education system that itself is being held to ethical issues concerning equal educational experiences in public schools, regardless of the social population served, is not an easily achieved goal (French 2005; Hollins \& Guzman, 2005). One possible avenue to support aspects of social justice and educational reform is to do so within the schools themselves by helping to prepare more socially aware educators. This article examines a more directed approach to shaping

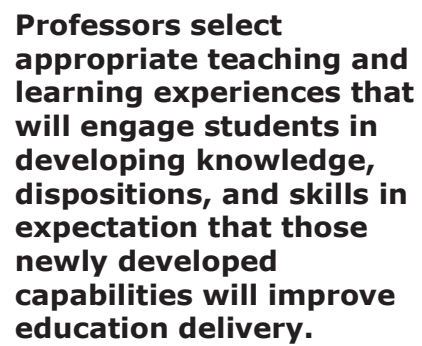
teacher identity by exploring a yearlong course designed to employ guided inquiry within a community of learners' perspective (Shulman, 2005). It is the intent of this course exploration to gain more understanding of how one can facilitate building sensitivity and action-oriented dispositions as part of the teacher identity development of future teachers.

\section{Context of Teaching and Learning}

In teacher education, professors select appropriate teaching and learning experiences that will engage students in developing knowledge, dispositions, and skills in expectation that those newly developed capabilities will improve education delivery. One way to guide students on this path is to focus instruction on the ongoing expansion of one's teacher identity. The development of teacher identity is a dynamic process that evolves over time in interaction with others (Cooper \& Olson, 1996). As stated by Bullough, Knowles, \& Crow (1992), "Teacher identity...is of vital concern to teacher education; it is the basis for meaning making and decision making" (p. 21). Therefore, it seems warranted that attention to teacher identity should be the foundation from which learning in the college and school 
classroom can be examined. Teacher identity should not be left to chance and in a program lasting one short year; it needs to be an integral part of the educational plan.

At any point in time, one's teacher identity becomes the lens through which conclusions are drawn and actions are directed. Instructional decision making and attitudes are shaped by this professional identity as easily as water flows through a filter (Campbell, 2005). A teacher candidate's belief system will strongly influence what they learn, how they perceive a situation, and how they will respond. This exploration of identity views the process as one that is not fixed but is an ongoing progression that is relational in nature and is likely to be multileveled where various contextual identities may exist (Beijaard, Meijer, \& Verloop, 2004). When there is conflict between identities, it is advantageous to provide an avenue for exploration and understanding through teacher education programming and instruction.

\section{Process of Exploration through Teacher Identity}

The process of exploring a course directed at shaping teacher identity focused on the following two questions: Could the building blocks of teacher identity be examined through course design and teacher candidate performances while engaged in yearlong field experiences? Would course elements focused on critical evaluation of educational issues and the process of inquiry become avenues for shaping sense of self and altering teacher behavior of two graduate level cohorts? This process of exploration is different from what is normally seen in teacher identity studies, which often look at smaller numbers of students and limit exploration to elementary student teachers rather than secondary student teachers (Britzman, 1994; Bullough \& Knowles, 1991;

Clandinin, 1986; Clandinin \& Connelly, 1996). The present examination looks at a larger number of students, both elementary and secondary level student teachers, and focuses on the content, delivery, and outcome products of

At any point in time, one's teacher identity becomes the lens through which conclusions are drawn and actions are directed. the course experiences.

Although teacher identity is ever changing, the direct approach to influencing its development in this particular teacher education program is a conscious directive to support the critical transition of the perception of self from a student to one as a teacher. The transition to seeing oneself as a developing teacher is an essential step to identifying one's power to influence change. Teacher candidates become more familiar with themselves as educators in the midst of learning and contributing in a collaborative group of educators (e.g. professors, other teacher candidates, master teachers, and other professionals in the schools). In an attempt to boost the development of teacher identity in a one-year master of arts in education and teacher credential program, a university in Southern California purposely designed the curriculum to focus upon the developing teacher identity and the ability to engage in educational change.

Given this challenge, a course entitled Teacher Identity and Vocation was designed to incorporate the use of action research, research-based service-learning projects, or self-directed inquiry as project choices in order to assist students in developing personal teaching identities sensitive to educational issues. The supposition of developing the course was to get teacher candidates thinking right away about the critical educational concerns and questions that will be evident in their role as educators; the hope was that if they perceived themselves as change agents, this may lead them to actively engage in educational problem-solving. 


\section{Setting and Participants}

Two cohorts attending a university in Southern California were followed during a yearlong teacher credential program. Students in this program completed a master's degree and credential in 11 months. They began their program in the fall and completed the program the following July. Each cohort contained 14 students pursuing either an elementary or secondary credential. A total of 15 graduate students pursued and obtained their elementary credential, and 13 obtained their secondary credential.

The students commit one year to the program; while working on their courses, they engage in student teaching placements in the surrounding community. The community has great diversity in placement settings. Some placements are suburban, while others meet the characteristics of urban communities with respect to the diversity of the population, large low income population, number of students eligible for free lunch, and being identified as title one schools. The diverse experiences bring richness to the many discussions that take place with their fellow teacher candidates, mentor teachers, and faculty facilitator. The intimacy of such a learning group enriches participation, resulting in deep discussion of commonalities and differences and perhaps more importantly, inquiring as to the possible explanations.

\section{Course Structure and Delivery}

The course is a one-unit per term, three-term course that is designed to shape teacher identity through a community of learners' perspective and guide individual students to explore answers to driving questions formulated during the course.

Students engage in group discussions concerning social issues and educational reform. Leadership, equal access, social justice, quality teachers, standard based instruction, authentic and experiential learning and assessmentbased decision making are some of the topics that are brought to the table for discussion. The realities of their classroom experiences help to define the realities within the world of practice.

The discussions often present more questions or need for clarity as students search out answers and bring them back to the whole group for further exploration. Shulman's (2005) community of learners format is followed in the context of the searching and sharing. Teacher candidates

The realities of their classroom experiences help to define the realities within the world of practice.

focus on specific questions or topics of concern and come back to the group as experts. The sharing of new information is then brought to the forum in the way of how certain problems might be solved. The course also directly connects their discussions and inquiry to their student teaching field experiences. The shared discussions and personal construction of understanding helps the student make sense of the four categorical sources of teacher identity--role models, past teaching experience, education course work, and past experiences as a learner (Knowles, 1992; Vinz, 1996)--while incorporating their fresh learning experiences into their new sense of self. By adding a course that supports students throughout the length of their program, the new teacher education candidates begin to quickly see the relationship and essential connections that research, practice, and classroom application can bring to their new learning context of teacher identity (HoffmanKipp, 2008). 


\section{Term Goals}

Term one focuses on discussion, learning, sharing, observing, and making connections to the real world. The final outcome of term one is for each student to have a driving question ready for investigation which includes a beginning researchbased review of literature. The second term looks at avenues of systematic study of questions and results in writing an inquiry proposal for carrying out a project to explore their selected driving question. Term three involves implementation of the project and developing the final outcome products of written paper and final public presentation of their inquiry project. Table 1 displays the focus of each term with their associated outcome products.

\section{Format Choices for Student Inquiry}

The students at some point, usually the end of the first term, decide on one of three approaches to studying their question: action research, research-based service-learning projects, or a self-directed inquiry project. These are often connected to how the student perceives the need of investigation. Some students will focus on the needs of the students and or community (i.e., service-learning), some on the actual teaching-learning process within the classroom (i.e., action research), while others will spend time seeking answers to a problem that is selfguided in terms of need (i.e., self-directed inquiry).

Questions are formed as students make connections in their learning, and guidance for these students is obtained through the literature and from in-depth conversations with the facilitating professor. The relaxed nature of the course allows for informal presentation of ideas for the community of learners to consider, and students are encouraged to connect theory and practice from

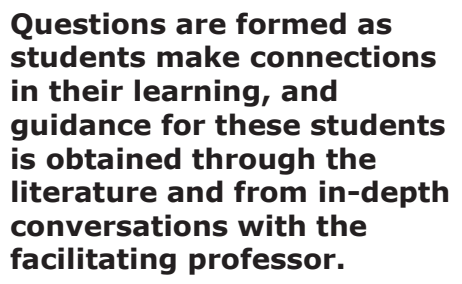

their courses and field assignments. In comparison to service-learning and action research, the projects in this choice are slower to develop in their final form, but usually end up having a more significant outcome product in terms of length and depth. As students begin to develop questions of personal concern, they are directed in even smaller groups or individually to investigate the related research.

\section{How the Inquiry Project Choices Inform Student Learning}

As stated above, the direction of the students' inquiry projects reflects the question and area of concern being investigated. Students are aware of the choices, and as their inquiry questions take form, they begin to consider how they will implement a plan for gaining more understanding. This leads to their selection of one of the inquiry paths. Each of the instructional strategies for inquiry servicelearning, action research, and self-directed inquiry are sound avenues for exploration and have been utilized in teacher education and in other disciplines. The following sections briefly describe the focus of the format for each inquiry choice.

Service-Learning

Service-learning projects are often selected when a student is focusing on a school community need. The National Service-Learning Clearinghouse (2005) defines service-learning as "a teaching and learning strategy that integrates 
meaningful community service with instruction and reflection to enrich the learning experience, teach civic responsibility, and strengthen communities" (p. 1).

The elements of integrated learning, collaboration, civic responsibility, and reflection as suggested by Karayna and Gathercola (2005), are used to guide teacher candidates in designing and implementing their service-learning projects. The project must noticeably connect their learning and values from the college classroom to a well- articulated goal of the project. The service must respond to an actual school community need, and the project should direct benefits to the students and or community members. Clearly, the teacher candidates benefit in terms of their learning and empowerment. Civic responsibility and collaboration are essential elements to the project planning; implementation is considered in project reflections. The project timeline, implementation, results, and personal reflection must be shared with the cohort community, as part of their research outcome product as well as the public forum as an avenue of disseminating the teacher candidates' work.

Table 1: Course Elements and Outcome Products per Term

\begin{tabular}{|c|c|c|}
\hline Term & Inquiry Descriptor & Outcome Goal \\
\hline Term One & $\begin{array}{l}\text { Readings and Discussions } \\
\text { Observations and Discussions } \\
\text { Wonderments and Exploration } \\
\text { Community of Learners I nquiry } \\
\text { Groups } \\
\text { Shared Expertise } \\
\text { Problem Solving } \\
\text { Defining A Driving Question } \\
\text { Beginning Review of Literature }\end{array}$ & $\begin{array}{l}\text { Wonderments Reflection } \\
\text { Inquiry } \\
\text { Group Presentations and } \\
\text { Problem Solving } \\
\text { Annotated Bibliography } \\
\text { Forming Inquiry Questions } \\
\text { Determining Venue of } \\
\text { Investigation (e.g. service- } \\
\text { learning, action research, } \\
\text { self-directed inquiry) }\end{array}$ \\
\hline Term Two & $\begin{array}{l}\text { Individual and Small Group Meetings } \\
\text { Appointments } \\
\text { Questions and Problem Solving } \\
\text { Completing Review of Literature } \\
\text { Writing a Proposal } \\
\text { Finalizing a I mplementation Plan }\end{array}$ & $\begin{array}{l}\text { Question and Discussion } \\
\text { Proposal } \\
\text { Inquiry Project Plan } \\
\text { Final Review of the } \\
\text { Literature }\end{array}$ \\
\hline Term Three & $\begin{array}{l}\text { Implementation / Application } \\
\text { Individual and Small Group Meetings } \\
\text { Whole Group Instruction } \\
\text { Analyzing and Discussing Results } \\
\text { Preparing Paper and Presentation } \\
\text { Establishing Professional Growth Plan } \\
\text { Final Public Dissemination of } \\
\text { Professional Work }\end{array}$ & $\begin{array}{l}\text { Implementation } \\
\text { Analysis and Discussion } \\
\text { Final Paper } \\
\text { Developing Presentation } \\
\text { Final Presentation for the } \\
\text { Teacher Education } \\
\text { Symposium }\end{array}$ \\
\hline
\end{tabular}

Action Research

Action research is a process that places the teacher candidate in the midst of learning while systematically applying research techniques to answer questions. It is not a direct application of scientific research but instead a process of evaluating and analyzing a practice that will serve to inform future classroom practice (Gould, 
2008). Action research is a systematic and thoughtful analysis of a practice (Hubbard \& Power, 1999) that is of interest to the teacher candidate and perhaps master teacher. It increases awareness and values while trying to establish an understanding of a research- based practice (Elliott, 2008, 2005).

Action research can serve as a pedagogical avenue to guide the teacher candidate, in the process of examining a particular educational practice using research techniques. The process of using action research for this yearlong course requirement begins with a question of wonderment and transforms into a systematic investigation to answer the question that is formulated and carried out in a classroom research project. The focus of action research in this setting is to engage in a process that will help to answer a question derived from the educational context. Engaging teacher candidates as they define such questions and explore possibilities in finding additional information to support their thoughts, allows for individual growth and understanding of educational practices that should affect future teaching. The sharing of these findings in both presentation and written form helps them to solidify what they have learned in an organized manner and subject it to others' questions and contributions.

\section{Self-Directed Inquiry}

Self-directed learning is a form of inquiry-based learning where the student directs inquiry to formulate questions and find answers about a subject of personal interest (Hutchinson, 2007). It provides the student with an avenue to investigate something personally and professionally relevant, devise questions that guide his or her inquiry, and aids in the construction of the knowledge in a personal and meaningful way. It is a powerful strategy for student-led learning which heavily relies on critical thinking skills and deep level learning (Roy, Borin, \& Kustra, 2003). It is similar to problem-based learning but provides a more open approach to investigate a particular area of curiosity or need. In this tradition the course allows for questions to surface from a teacher candidate's personal need to know or do.

\section{Measures and Products Analyzed}

\section{Professor Narratives}

During the yearlong course, the facilitating professor assigned to the two cohorts kept a narrative class journal in which class events and reflections were recorded. The primary purpose was simply to see what developed as time passed and as a record of course topics, structure, delivery, reflection, and outcome was noted. The record of information was created in part to evaluate and to inform future sections of the course.

\section{Student Reflections}

Periodically, reflections on the process were obtained along with the final outcome products (i.e., papers or documents and presentations). These served as the data in which projects were classified and themes emerged in the teacher candidates' responses. In addition to these artifacts, the facilitator of the course and yearlong support person wrote short reflective evaluations that served to guide the process and were used primarily to shape the class experiences. Final course evaluations were also reviewed for student feedback and reflective evaluation of the course experiences. 


\section{Outcome Products}

The final master's project presentation came in the form of a 30-minute session presentation, round table presentation, or poster presentation. The written component was in the form of either a paper or outcome artifact. The paper often followed the format of a research article or a project report which included common elements such as research base, rationale, procedure, and outcome findings. Other written outcome products were in the form of a final artifact that represented their self-directed inquiry project. These often took the form of a research paper, instructional manual, or review of knowledge and conclusion to a particular educational problem or concern.

\section{Results and Discussion}

Table 1 provides the term highlights and outcomes per term that were established from the professor's narrative record. Other elements identified in the narrative were as follows:

Term One

- In-class experiences are developing from focusing on the learner and moving outwardly to the classroom, school system and community.

- $\quad$ Students begin to question and wonder about the events in which they were engaged. They posed questions, held discussions, and eagerly gave opinions.

- Students are becoming much more comfortable with self-initiated exploration and sharing among themselves and with the facilitating professor.

- First term classes seem to have been primarily making connections between class experiences and field experiences that either connected or seemed to discount what they were learning. Many students became comfortable speculating about the differences, and rich conversations of wonderment evolved.

- Annotated bibliography outcomes differed in focus, length, and depth. They reflected a student's search for answers, sometimes not arriving at the appropriate information until late in the term.

Term Two

- The second term initial class was very productive, where students applied research readings to turning the wonderment into measureable questions.

- The early outcome of term two was a proposal and timeline of their project.

- Individual appointments are heavily needed at this juncture (midterm of term two)

Term Three

- The final term, the heaviest in work load and more individual in nature, consisted of implementing their research-based service-learning, action research, or self-directed inquiry projects.

- Following the conclusion of their projects, candidates prepared a final outcome product that resulted in both a presentation and written outcome.

- In-class cohort presentations were superior in that they used it as a first run at disseminating their work. Teacher candidates were very supportive of each other in helping to improve delivery of information, adding needed 
information and in avenues for sharing the final product. There was a direct connection between shared support and the changes made for the final presentations.

- Final dissemination among educators, community members, administrators, and classmates was rewarding for everyone in attendance.

\section{Projects Final Outcome Products}

Since the inception of the course, each term produces projects that fall under the main categories of service-learning, action research, or self-directed inquiry. Table 2 provides a few selected projects from each area identifying the outcome projects and the focus of the change agent derived from the experience. The selected projects show the common thread of either social justice or educational reform.

In reviewing the project completed in the two sections of the course, a total of 28 projects were submitted. Each project was identified as one of the three pedagogical categories of action research, research-based service-learning, or selfdirected inquiry. Table 3 displays the percentages of students completing the various types of outcome projects per category.

In the two sections evaluated, $46 \%$ of the students conducted researchbased service- learning projects, while $18 \%$ conducted action research projects and $36 \%$ of the students designed self-directed inquiry projects. Further analysis using the type of credential the candidates were seeking provided some direction in drawing conclusions about the reason for the chosen projects.

Of those students conducting service-learning projects, 85\% (11 of 13) were placed in a professional development school setting which were yearlong student teaching placements that may have slightly increased the likelihood of a service project taking place. All of the students engaged with service-learning projects were multiple subject students who served in elementary schools. This could have contributed to selecting projects that could easily be implemented with a controlled population outside of a specific classroom setting. All of the servicelearning projects served students and parents associated with a larger population than those students from the teacher candidates' student teaching placement.

Of the $18 \%$ ( 5 out of 28 ) students conducting action research projects, two students were multiple subject students placed at the elementary professional development school and three students were single subject students placed at different secondary school placements (non-PDS) teaching math and English. Of the $36 \%$ of students engaged in self-directed inquiry projects, all were single subject students placed in secondary placements, where they taught English, science, or history.

In comparing multiple and single subject students' choice of project, multiple subject students selected service-learning or action research projects, whereas single subject students selected either action research or self-directed inquiry projects. Single subject students are required to complete two placements, one at the middle school level and one at the high school level. Having less time to investigate the situation in which they were participating may have discouraged taking on service-learning projects. 
Table 2: Final Inquiry Products

\begin{tabular}{|c|c|c|c|c|}
\hline $\begin{array}{l}\text { Project } \\
\text { Category }\end{array}$ & $\begin{array}{l}\text { Project } \\
\text { Area } \\
\text { Description }\end{array}$ & Sample & Outcome Projects & $\begin{array}{l}\text { Change } \\
\text { Agent } \\
\text { Focus } \\
\end{array}$ \\
\hline $\begin{array}{l}\text { Action } \\
\text { Research }\end{array}$ & $\begin{array}{l}\text { Teacher } \\
\text { candidate } \\
\text { applied } \\
\text { action } \\
\text { research } \\
\text { within the } \\
\text { school } \\
\text { system or } \\
\text { school } \\
\text { setting. }\end{array}$ & $\begin{array}{l}1 . \\
2 .\end{array}$ & $\begin{array}{l}\text { Higher Education Parent Workshop: A } \\
\text { parent workshop on setting higher } \\
\text { education goals for their children. } \\
\text { A Study of Math Methods: Exploratory } \\
\text { study of secondary math instruction. } \\
\text { Technology and Language Development: } \\
\text { Project focused on using technology to } \\
\text { motivate student language development } \\
\text { and fluency. } \\
\text { Case Analysis of Secondary Education } \\
\text { Problem Solving: An exploration of } \\
\text { teachers collaborating within the system } \\
\text { to meet needs of students in their } \\
\text { classrooms. Final product outlines the } \\
\text { process and final product solution to the } \\
\text { identified problem }\end{array}$ & $\begin{array}{l}\text { Social } \\
\text { Justice, } \\
\text { Equal Access } \\
\text { to Education } \\
\text { Secondary } \\
\text { Instruction } \\
\text { and Methods } \\
\text { Social } \\
\text { Justice, } \\
\text { English } \\
\text { Language } \\
\text { Learners } \\
\text { Education } \\
\text { Reform to } \\
\text { Meet Diverse } \\
\text { Learners' } \\
\text { Needs }\end{array}$ \\
\hline $\begin{array}{l}\text { Service- } \\
\text { Learning }\end{array}$ & $\begin{array}{l}\text { Projects } \\
\text { primarily } \\
\text { focused on } \\
\text { an identified } \\
\text { question } \\
\text { associated } \\
\text { with a 'need' } \\
\text { identified in } \\
\text { the school. }\end{array}$ & 3. & $\begin{array}{l}\text { University Week: A weeklong, after } \\
\text { school program focused on introducing } \\
\text { upper elementary students and parents } \\
\text { to college. } \\
\text { Five Week After School Program on } \\
\text { Family Literacy and Nutrition, including } \\
\text { family literacy experiences and providing } \\
\text { groceries for families } \\
\text { School Talent Show: Instruction on } \\
\text { producing a show culminating in a school } \\
\text { wide and community production. } \\
\text { Serving the Sciences: A cross grade level } \\
\text { and differential learning experience for } \\
\text { elementary school children. }\end{array}$ & $\begin{array}{l}\text { Social } \\
\text { Justice, } \\
\text { Equal Access } \\
\text { to Education } \\
\text { Social } \\
\text { Justice, } \\
\text { English } \\
\text { Language } \\
\text { Learners } \\
\text { Multiple } \\
\text { Intelligences, } \\
\text { Arts in } \\
\text { Schools } \\
\text { Social J ustice } \\
\text { and } \\
\text { Promoting } \\
\text { the Sciences }\end{array}$ \\
\hline $\begin{array}{l}\text { Self- } \\
\text { Regulated } \\
\text { Inquiry }\end{array}$ & $\begin{array}{l}\text { Projects } \\
\text { were } \\
\text { personally } \\
\text { formed and } \\
\text { created by } \\
\text { identified } \\
\text { need of the } \\
\text { teacher } \\
\text { candidate. }\end{array}$ & 2. & $\begin{array}{l}\text { Differentiated Learning: How to meet } \\
\text { the learning needs in secondary science } \\
\text { classes. Curriculum Model for teaching } \\
\text { Science at the Secondary Level. } \\
\text { Health Issues for Adolescent Girls: An } \\
\text { Instructional Manual for Discussion } \\
\text { Based Health Instruction. }\end{array}$ & $\begin{array}{l}\text { Social } \\
\text { Justice, } \\
\text { Promoting } \\
\text { Equal Access } \\
\text { in Science } \\
\text { Learning } \\
\text { Social J ustice } \\
\text { and } \\
\text { Adolescent } \\
\text { Girl Health } \\
\text { and } \\
\text { Development }\end{array}$ \\
\hline
\end{tabular}


Table 3: Percentages of Students Participating per Project Classifications

\begin{tabular}{|l|l|}
\hline Project Classification & Percentage of Students \\
\hline Research-Based Service-Learning Projects & $46 \%$ \\
\hline Action Research Projects & $18 \%$ \\
\hline Self-Directed Inquiry Projects & $36 \%$ \\
\hline
\end{tabular}

The social justice change agent focus for each area varied. The majority (79\%) of the projects fell into the realm of social justice where they addressed equal access, English language learners or educational reform. Only six $(21 \%)$ of projects fell outside of the realm of social justice (projects not connected with social justice issues covered in their program). Those six projects focused on content area-specific action research or self-directed inquiry projects. Those conducting these six projects were all single subject teacher candidates.

\section{Reflection: Student Perceptions of the Learning Process}

Students pursuing their degree and credential in this one-year program put forth a great deal of effort and commitment to completing their individual goals. The transformational process that took place from a teaching and learning viewpoint is complex, where candidates pulled from courses, field experiences, community of learner discussions, and their selected projects, integrating these experiences to construct understanding of their teacher identities and roles as change agents in education.

A review of their reflections and final written documents for their outcome projects were the tools evaluated for themes. Students' perceptions about their experiences were expressed as deep, introspective, and integrative in nature. Students shared a process where the project grew from a perceived 'need situation' based on their site placements where the need may be site specific or teacher candidate specific. If it was not based on a personal or site need, the candidates began their project development from college course content and discussions which became entwined with their

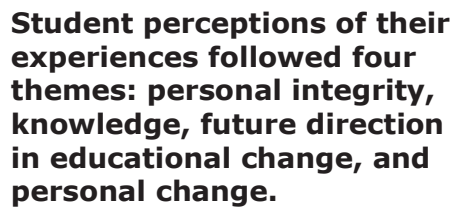

observations of practice. In either case, students expressed considerable satisfaction and competency as future educators with the ability to promote change.

Student perceptions of their experiences followed four themes found in their discussions: personal integrity, knowledge, future direction in educational change, and personal change. Within the reflection pieces that accompanied their final products, $98 \%$ of the students mentioned personal change, $87 \%$ addressed future direction as a change agent, $82 \%$ addressed educational knowledge as a primary response, and $76 \%$ shared contents that focused on personal integrity.

\section{Concluding Summary and Remarks}

The intent for the yearlong course to develop a sense of identity, vocation, and inquiry was evident in the student projects, discussions, and final reflections. The observed communication among teacher candidates, community members, educators, and instructors were consistent with this conclusion as observed during the final public forum for sharing their work. Master teachers, administrators, and field supervisors informally made comments related to the teacher candidates as being highly motivated and personally committed to making positive changes in education.

Volume $5 \bullet 2010$ 
Teaching and learning is a deeply personal and social act of preparing students to 'own' their knowledge. The application of the teaching-learning approaches of service-learning, action research, and self-directed inquiry in the midst of exploring problems or project-based experiences should be helpful in any course where high engagement, problem solving, and application are primary goals. It opens the realm of exploring how future practitioners in any field think and adopt a professional identity of engagement and change. The course exploration should provide a blueprint for other courses designed to shape teacher identity, and serve as a resource for application to other practice-oriented academic areas.

The perspective presented in this course and its contribution to the students' masters' experience has suggested that service-learning, action research, and self-directed inquiry projects are strong avenues for developing students' knowledge and teacher identity. The course is an effective way to get students personally engaged as learners and prepared to take on the role of a change agent in education.

In reviewing the course evaluations, students rated highly their abilities to problem solve, competencies in understanding the teaching and learning environment and often reported themselves as growing, capable educators who could make an educational difference in the future.

\section{References}

Beijaard, D., Meijer, P., \& Verloop, N. (2004). Reconsidering research on teachers' professional identity. Teaching and Teacher Education, 20(2), 107-119.

Britzman, D. (2003). Practice makes practice: A critical study of learning to teach. Albany, NY: State University of New York Press.

Britzman, D. P. (1994). Is there a problem with knowing thyself? Toward a poststructuralist view of teacher identity. In T. Shanahan (Ed.), Teachers thinking, teachers knowing: Reflections on literacy and language education (pp. 53-75). Urbana, IL: National Council of Teachers of English.

Bullough, R., Knowles, J., \& Crow (1992). Emerging as a Teacher, London, UK: Routledge.

Bullough, R., \& Knowles, J. (1991). Teaching and nurturing: Changing conceptions of self as teacher in a case study of becoming a teacher. International Journal of Qualitative Studies in Education, 4(2), 121-140.
Campbell, S. (2005). Ariadne's thread: Pre-service teachers, stories and identities in teacher education. Unpublished doctoral dissertation, University of Colorado at Boulder.

Clandinin, D. \& Connelly, E. (1996). Teachers' professional knowledge landscapes: Teacher stories--stories of teachers, school stories-stories of schools. Educational Researcher, 25(3), 24-30.

Clandinin, D. (1986). Classroom practice: Teacher images in action. London, UK: Falmer Press.

Cooper, K., \& Olson, M. (1996). The multiple 'I's of teacher identity. In M. Kompf, D. Dworet, \& R. Boak (Eds.), Changing research and practice (pp. 78-89). London: Falmer Press.

Darling-Hammond, L. \& Bransford, J . (2005). Preparing Teachers for a Changing World. San Francisco, CA: Jossey-Bass.

Elliott, J. (2008). 'The Birth of a School Academy in North Norwich: a case study', Forum, 50 (3), 18-22.

Elliott, J. (2005). 'Becoming Critical: the failure to connect', in Educational Action Research, 13 (3). 
French, J. (2005). Culturally responsive pre-service teacher development: A case study of the impact of community and school fieldwork. Unpublished doctoral dissertation, University of Connecticut.

Gould, M. A. (2008). Teacher as Researcher; A paradigm for professional development. Kappa Delta Pi Record, 45(1), p5-7.

Hoffman-Kipp, P. (2008). Actualizing democracy: the praxis of teacher identity construction. Teacher Education Quarterly 35(30), 151-160.

Hollins, E., \& Guzman, M. (2005). Research on preparing teachers for diverse populations. In M. CochranSmith \& K.M. Zeicher (Eds.), Studying teacher education: The report of the AERA panel on research and teacher education (pp. 477-548). Mahwah, NJ: Lawrence Erlbaum Associates.

Hubbard, R. \& Power, B. (1999). Living the questions: A guide for teacher researchers. Portland, ME: Stenhouse.

Hutchings, B. (2007). Enquiry-based Learning: Definitions and Rationale. University of Manchester, UK.
Karayan, S. \& Gathercoal, P. (2005). Assessing service-learning in teacher education. Teacher Education Quarterly, 32(3), 79-82.

Knowles, J. G. (1992). Models for understanding preservice and beginning teachers' biographies: Illustrations from case studies. In I. Goodson (Ed.) StudyingTeachers' Lives. Columbia University, NY: Teachers College Press. 99-153.

National Service-Learning Clearinghouse. (2005). Servicelearning is.... Retrieved May 15, 2009 from http://servicelearning.org/whatservice-learning

Roy, D., Borin, P. \& Kustra, E. (2003), What Is Unique about Inquiry Courses? Center for Leadership in Learning, McMaster University, Canada, Retrieved April 9, 2009 from http://www.mcmaster.ca/cll/inquiry/ good.inquiry.question.htm

Shulman, L. S. (2005). Signature pedagogies in the professions. Daedalus, Journal of the American Academy of Arts and Sciences, 134(3), 52-59.

Vinz, R. (1996). Composing a teaching life. Portsmouth, $\mathrm{NH}$ : Boynton/Cook

Kathy L. Church is an Associate Professor in the Graduate School of Education and Psychology at Pepperdine University. She received the Howard A. White Award for Teaching Excellence and has presented nationally and internationally. Her research interests include teaching and learning, student engagement and teacher identity. 